\title{
Pedagogical Conditions of University Students Professional Core Competencies Formation in the Process of Humanitarian Training
}

\author{
Alsu R. Nabiyeva ${ }^{1}$, Yuliya L. Kamasheva ${ }^{2}$, Elikanida P. Mutavchi ${ }^{3}$, Albina N. Kudyasheva ${ }^{4}$, Alfiya M. \\ Ishmuradova $^{4}$, Nina D. Apraksina ${ }^{5} \&$ Vera V. Murugova ${ }^{1}$ \\ ${ }^{1}$ Kazan Cooperative Institute (Branch) of the Russian University of Cooperation, Kazan, Russia \\ ${ }^{2}$ Institute of Economics, Management and Law, Kazan, Russia \\ ${ }^{3}$ Immanuel Kant Baltic Federal University, Kaliningrad, Russia \\ ${ }^{4}$ Kazan (Volga region) Federal University, Kazan, Russia \\ ${ }^{5}$ Almetyevsk State Oil Institute, Almetyevsk, Russia \\ Correspondence: Alsu R. Nabiyeva, Kazan Cooperative Institute (Branch) of the Russian University of \\ Cooperation, 420081, Kazan, N. Yershova Street, 58, Russia. E-mail: alsunab@mail.ru
}

Received: June 13, 2015 Accepted: June 21, 2015 Online Published: June 29, 2015

doi:10.5539/jsd.v8n6p60 URL: http://dx.doi.org/10.5539/jsd.v8n6p60

\begin{abstract}
The development of university students' professional core competencies today is one of the urgent problems in their humanitarian training. It is advisable to take into consideration the core competencies as a new unit of measurement in humanitarian education of a student - a future specialist, focusing on pedagogical conditions of their formation and results of learning process, which are considered not as the amount of learned knowledge, skills, but humanitarian ability to use this knowledge in different situations creatively. The study aim is to justify scientifically pedagogical conditions' structure and content of university students' professional core competences' formation in the process of their humanitarian training. The leading research method is the method of pedagogical conditions' complex modeling of university students' professional core competencies formation in their humanitarian training process. The article presents the theoretical and methodological bases of pedagogical conditions' complex designing of university students' professional core competencies' formation in the process of their humanitarian training: the concept of competence-based approach, declared in the FSES of HPE requirements (federal state educational standards of high professional education), as productive ideas of humanitarian training modernization; variable model of core professional competencies' development; the structure and content of scientific and methodological support. Article materials are designed for university teachers of humanitarian disciplines, educators, young scientists, postgraduates, students of the advanced training system and teaches' retraining. They can be profitable for specialists of enterprises' technical departments, undergraduates and University students, interested in research work.
\end{abstract}

Keywords: humanitarian training, humanitarian education, didactic unit, core competence, competence approach, modeling, scientific and methodological support, pedagogical conditions

\section{Introduction}

\subsection{The Relevance of the Study}

The relevance of the study is explained by current transformations taking place in the educational process of higher education, the search for new models and approaches to humanitarian training of students - future specialists of new generation, demanded by society as citizens with an active lifestyle, by the labor market as a competent, creative professionals, by the personality itself as self-identified and self-transformed intellectual. Educational strategies of students' humanitarian training presented in FSES of HPE requirements (2009), in connection with such orientations emphasize the need for subjects (Humanities) knowledge conversion from the main goals of the educational process into a developing means of core professional competencies of university graduates' self-determination and self-actualization in the labor market. The universities' focus on the development of core professional competencies of the individual student determines the update of the entire structure and content of the educational environment of the University, the subordination of all parts of the implementation of innovative directions. According to leading experts in the field of design and implementation 
of university students' core professional competencies (Verbitsky, 2004; Grebenyuk, 2000; Zimnaya, 2003; Slastenin, 2003; Khutorskoy, 2003; Shchedrovitsky, 1993; Masalimova et al., 2014; Telegina, Galimova \& Masalimova, 2015) the primary objective in this process is to create the necessary pedagogical conditions relevant to the goals of innovative transformations. To these conditions, they include:

- psychological and pedagogical conditions (an enriching educational environment's creating in the process of humanitarian disciplines' study, development of mechanisms of incentive motivation to self-development and self-transformation of teachers and students personalities, monitoring of professional and personal students' development);

- organizational and managerial conditions (theoretical and practice-oriented justification of the mechanisms how to involve the teaching staff in the process of formation of core professional competencies in Humanities' teaching);

- structural and content conditions (systematization of core and subject competencies in the content of social disciplines and in the content of elective courses in Humanities);

- technological conditions (designing and implementing of interactive, design technology, corporate training, design training, simulation planning, developing diagnostics, the method of "case studies", and other creative technologies necessary for core professional competencies' formation);

- test and diagnostic conditions (development of criteria and evaluation parameters to monitor the formation quality of core professional competencies' in the humanitarian training of students);

- scientific and methodological conditions (designing and implementing of competence-based approach's conceptual ideas, organizational structure, content, and technological components of training and methodological support of core professional competencies' formation process, innovative versions of manuals, guidelines, glossaries, reference books, laboratory and practical tasks, independent projects, students' research activities, plans and recommendations for course and degree planning, etc.).

\subsection{Regularities}

In addition, the complex of conditions defines the essence of the system and functional regularities of innovative renewal in university students' humanitarian training, which is subordinated to the purpose of core professional competence's creating of the individual.

\subsubsection{System Regularities}

- the efficiency of students' core professional competencies' formation in humanitarian training is achieved with respect to the integration of education, science and manufacture;

- the quality of students' training is enhanced if entities' requirements of integrative interaction between education, science and manufacture are met;

- formation and development of students' core professional competencies in the process of their humanitarian training occurs in accordance with the relevant direction;

- focus on work in the industry and the competitiveness of future specialists are provided with a variety of forms of social partnership with research institutions, enterprises and institutions industry, representatives of public structures;

- creativity of humanitarian training is developed in accordance with scientific and professional growth of teachers;

positive socialization of the University graduate is accompanied by the presence of formed socio - professional skills and core professional competences in accordance with the specialty;

- готовность студента - будущего специалиста к инновационной самостоятельной деятельности формируется в условиях развития мотивационно - творческой активности личности.

- the willingness of the student- future specialists to innovative independent activity is formed in the conditions of motivational and creative activity development of the individual.

\subsubsection{Functional Regularities}

- effective selection and structuring of educational material while maintaining the integrity of fundamental, interdisciplinary, and innovative scientific and methodological support of the competence-based approach to humanitarian training;

- qualitative development of students' core professional competencies through the content of their humanitarian 
training in the modular design of training material and project technologies implementation;

- the interiorization efficiency by the students of the training humanitarian content provided training organization taking into account the motivational sphere of personality in core professional competencies' formation.

\section{Methodological Framework}

\subsection{Theoretical and Methodological Base of the Research Problem}

Theoretical and methodological basis of research are built up of the concepts:

pedagogical design of vocational education goals (Bespalko,1995; Grebenyuk, 2000; Novikov, 2003);

professional activity modeling (Kirsanov, 2000; Kondratiev, 2000; Kuzmina, 2001; Shchedrovitsky, 1993);

activity and personality - oriented approaches to learning (Zimnaya, 2003; Leontiev, 1975; Serikov, 1999);

- humanization and humanitarization of vocational education (Bestuzhev-Lada,1996; Volovich, 2008; Zapesotsky, 2003; Nigmatov, 1993; Rozov, 1993);

- the competence approach to vocational education (Baidenko, 2006; Zimnaya, 2003; Khutorskoy, 2002);

- competence-based approach to humanitarian training of students (Nurutdinov, 2010; Raven, 2002; Khutorskoy, 2003; Choshanov, 2011; Shchelkunov, 2010);

- project - oriented approach to humanitarian training of students (Ibragimov, 2012; Kolesnikova, 2005; Novikov, 2002; Strongin \& Grudinsky, 2008).

\subsection{Key Notions}

In the process of study discursive content of key concepts was used:

- humanitarian training in the context of the development of university students' core professional competencies is a teaching process of design and implementation of humanitarian education of the university individual student- the future specialist in the study of social disciplines and Humanities;

Humanities education - the type of education that is able to reproduce and develop culture; methodologically flexible, creative intelligence of the individual, based on a set of knowledge, competencies, personality traits, attitudes, beliefs, socio-cultural norms, values, ideals, traditions, formed in the process of studying of humanitarian disciplines;

didactic unit - element of the educational material content presented in the form of approved study curriculum within a particular professional discipline or educational subjects; one of the subject topics, which should be studied in the process of specialists' training on the discipline;

- core competence - a set of interrelated qualities of the person specified in relation to a range of objects and processes; intercultural and interdisciplinary knowledge, skills and abilities needed for personality to adapt and to fulfill productive activities in various professional communities; a meta-subject, a universal character;

- competence approach, an educational strategy based on innovative instrumental constructs: competence, competencies, and net professional qualities, together representing a core qualification of the individual specialist, focused on productive realization of his or her intellectual and creative potential, motivated and ready to work, to self-realization and self-transformation in complex socio - professional conditions of transforming society;

- modeling - study method of objects, processes, phenomena on the basis of their reconstruction, identically reproducing the modeled objects, and providing access for their thorough and comprehensive investigation;

- scientific and methodological support of organizational - pedagogical and methodological mechanisms for practical application of scientific results in the activity of education entities on the methodological, theoretical and methodological levels;

- pedagogical conditions - a set of organizational - structural, content, technological, criteria-based mechanisms of the university pedagogical system, creating an innovative learning environment focused on the development of core professional competencies of the individual student - the future competent specialist for contemporary labor market.

\subsection{Productivity Criteria Base of Pedagogical Conditions' Complex}

Productivity criteria base of pedagogical conditions' complex is presented by:

- criteria of formation for meta core professional competencies (motivation: the willingness of students to 
participate in the implementation of core competences; the cognitive aspect: the possession of knowledge of content being taught; activity aspect: the experience of manifestation in a variety of standard and non-standard situations; axiological aspect: the attitude to the content and object of core professional competencies' implementation; the aspect of the emotional - volitional reflection);

- the criteria of disciplines' content knowledge learned by the students(motivation to receive knowledge, volume of knowledge, stability of knowledge, system knowledge, integrity, knowledge, academic mobility of knowledge);

- evaluation criteria of students core professional competences ( to make their own reasoned decisions; to apply knowledge in a changing environment of social practice, to make reasonable conclusions; to design personal, educational and socio - professional trajectory of activities; commitment to innovation; self-identification, critical thinking);

- control and measuring materials of pedagogical conditions complex's productivity (the relationship matrix of competencies and didactic units, monitoring the of core professional competencies' formation, self-evaluation and evaluation by independent experts of requirements' implementing of the federal state educational standards of high professional education in humanitarian training of students, Eidos - the test of scientific and methodological support).

\section{Results}

\subsection{The Conceptual Environment of the Competence Approach}

It is determined by the transitivity of the structure and content of humanitarian training, creating for university students educational environment for personal potential's realization, the generated level of competence as a set of humanitarian knowledge, abilities, skills, qualities, experience, socio-cultural and socio - professional mobility and adaptability in accordance with the personal needs and the needs of the labor market.

The results of the study conducted show that the overall conceptual idea of the competence approach to the students' core professional competencies' formation in humanitarian training in today's environment is expressed in its focus on integrated development of knowledge and ways of socio - professional activity, providing the individual with conditions for successful functioning in important spheres of life in the interests of the individual itself, society and the state. This focus of humanitarian training determines the solution of critical problems of the ideas' implementation of competence-based approach, such as:

- the requirements' implementation of the FSES of HPE (federal state educational standards of high professional education) on the harmonization of knowledge, abilities, skills, qualities, students' experience, which are presented as part of competencies;

- designing and implementing of a professional's predictive model on the basis of the competence approach's provisions on the relationship of core professional competencies and qualifications;

- design of teaching plans and educational curricula based on the training modules focused on the development of core professional competencies;

- design of innovative educational technologies, reflecting the nature of the research, design, interactive, practice - oriented educational activity of students;

- using of the control and measuring materials (matrices of the relationship of competencies and didactic units of Humanities disciplines; accounting and credit units, score - rating indicators, Eidos - tests, etc. on the current criteria) in the planning and assess process if there is the complexity of the formation process of students' core professional competences;

- criteria identifying of mastered by the students skills, their stability, consistency, completeness, mobility;

- definition of the mastered competencies' evaluation (handling of competencies, willingness to design their own development trajectories, alternatives' choices, self-identity, readiness for extreme situations, willingness to take responsible decision-making).

The solution of these tasks is in direct dependence on strategic components of the competence approach to the formation of core professional competencies of students in humanitarian training:

- science - based models of formation of students' core professional competences, based on the integration of fundamental, substantive and professional training;

- goals, objectives, levels of competences' development in humanitarian training (cognitive, value, motivation, activity); 
- the students ' mastery of the invariant part of knowledge that constitute the methodological basis for the creative development of the personality in the modern dynamically developing socio-cultural and socio professional situation;

- variability of training, offering students a wide choice of educational curricula based on personal abilities, interests and needs;

- continuity of education, which is understood as the creation and development of a system of interrelated professional and educational programs, including programs of further education, ensuring the completeness of each educational stage and giving the opportunity to interrupt education at any level to enter the world of work or continue education in another field or in another educational institution (Novikov, 2002);

- the harmonization of the requirements of the University to the qualities of future specialists training with labor market requirements to the expected qualities of a University graduate.

Established strategic components of competence-based approach to humanitarian training of students create a basic core of conceptual environment which is necessary for rethinking the goals, objectives, structure, content and key technologies of students' professional competence formation.

\subsection{The Model's Structure and Content of University Students' Core Professional Competencies' Formation in the Process of Their Humanitarian Training}

The results of the study suggest that the model of core professional competences' formation in the process of humanitarian training is multi-level, theoretically and practically grounded didactic construct, within which holistic educational process is developing that has its purpose, content, principles, functions, methods, structural elements, technology, criteria base. Analysis of models of different nature (Kirsanov, 2000) conducted in the study allow to determine the general principles for their effective functioning: the integrity of the model, i.e., the high degree of interrelation of all its elements; the continued strengthening of the connections between elements; ensuring compliance of internal organization of the model and the external environment in which it operates to objective requirements necessary for its implementation and development; ensuring a high degree of model items' conformity to the purposes for which it was created.

In relation to models of students' core professional competencies' formation in humanitarian training the high level of significance for its design are socially and professionally important qualities of future specialist, represented in the content of the job description - professiogram (description of the main types of educational and professional activity, meta subject and subject competences that ensure their success), technogram (the combination of personal, including professional skills of students - future specialists, reflecting the requirements of the employer to the quality of training and recommendations to the formation of competencies) and psychogram (the willingness of the individual to professional activity: sustainable orientation of the personality, the skills of life strategies' choice, socio-cultural value orientations, orientation to self-determination, skills of reflection and self-reflection, will, intuition, self-organization, ability to plan working hours, keep a healthy lifestyle).

The model's content design involves:

1. Theoretical justification:

- formation of information base of educational - scientific knowledge;

- goals and objectives' defining of the content of students' humanitarian training;

- construction of conceptual schemes, projects of educational software documentation, the interrelation's justification of content's elements in the Humanities training;

- construction principles' definition of the didactic modules' content in humanitarian training;

- categorical apparatus' rethinking of core professional competences' content in the teaching of Humanities;

- scientific and methodological justification of didactic and methodological forms and methods' choice of designing the model.

2. Structural - semantic update of the content of humanitarian training in the boundaries of the created core professional competencies:

- scientific substantiation of principles of content and structure selection of the educational material;

- definition of theoretical knowledge system, providing profoundness of training and practical knowledge that form the basis of professional competence; 
- interdisciplinary links' establishing in linked fields of professional activity;

- major components' selection in the content of humanitarian training: the invariant part, which describes and promising for modern production (industry) technologies, technical objects, mechanisms, etc.; the professional part that combines a professionally directed knowledge, selected in accordance with the groups of occupations; the specialized parts, including concepts and theory, selected in accordance with the students' specialization; the ideological part, combining socio - humanitarian knowledge, providing ideological and socio-cultural orientation of educational knowledge.

3. The content's methodical provision of the model of students' core professional competencies formation:

- student process map's preparation (goal setting, tasks' designing for independent work, forms and methods of training, methods of diagnosis and corrective work);

- taking into account of students' individual and age peculiarities;

- individualization and differentiation of work with different groups of students;

- features of teachers and students co-creation;

- students' knowledge interiorization.

\section{Process provision}

Core professional competencies focus the humanitarian training on an innovative approach to the use of educational technology, which are identical as to aims, objectives, content of the of core competencies' formation, so to the content of the studied Humanities. Among these technologies, as it is evidenced by the results of the study, as close as possible the design, interactive and computer technologies are used for the tasks' solution of core professional competencies' formation. The established integrity of technologies is based on the full development of cognitive, intellectual activity of students, on professionally important competences' development, such as independent formulation of the problem, objectives, hypothesis, objectives, design future of work plans, implementation, evaluation, quality control of the final product, etc.

\section{Criterion software.}

The revealed and justified criteria indicators in the process of the conducted research allow allocate universal criteria of model's efficiency of students' core professional competencies' formation in humanitarian training: generalization, which manifests itself in students' readiness to the competences' transfer in different areas and types of activity and functionality, characterized by their willingness to be included in a particular activity and to the self-evaluation of this activity results.

The dominant characteristics of core professional competencies that are formed in the process of humanitarian training - are motivation in mastering, as the willingness of application; possession of the necessary knowledge; experience of application in standard and extreme situations as activity aspect; value attitude to the application object; emotional regulation of the application's process and outcome.

Identified indicators of core professional competences are above-professional by nature and manifest themselves in any activity, but as for humanitarian training, they possess specificity, due to the content of the studied material. This is primarily the competences of the axiological orientation, self-improvement, self-transformation, social interaction, communication, educational activities, practice - oriented activities of information technology, professional mobility, correction, qualitative, etc.

\subsection{Scientific - Methodical Support of Students' Core Professional Competencies' Development in the Process of Humanitarian Training}

In this study, the process of organizational - pedagogical and methodological mechanisms' development for the implementation of scientific results in education's entities activity is defined. This definition reveals the variety of relationships and dependencies, multifactorial manifestations in competence-based humanitarian training implementation that facilitates scientific and methodological support of the students' core professional competencies' formation in methodological, theoretical and methodological levels.

\subsubsection{Methodological Level}

This level is based on the concept of competence based approach to Humanities teaching. It is defined as a multi-level formation that contains interrelated elements: objective, educational information, means of pedagogical communication between teacher and students, forms of their work, and implementation kinds of pedagogical supervision of training and other students' activities. The unifying link in the relationship functioning of the installed items is the joint activity of teacher and students. 
The effectiveness of the methodological level as determined by the quality of university professors' scientific methodical training, because it includes the use of trends in the socio - economic development of the state, society and manufacture, the leading ideas of professional identity formation and the improvement of their training; ideas and concepts in related Humanities and professionally - relevant disciplines; a synthesis of traditional and innovative experience; identification of efficiency factors of socio - professional activity of graduates in the workplace; along with the competence-based approach, justification of modular competency, design task, design and technology and other modern approaches' use to students' training, determining of the ratio of these approaches in the process of humanitarian training of students; conceptual approaches to the planning and implementation of educational plans and curricula, educational content, teaching technology, reflecting the essence of the students' core professional competences' formation.

\subsubsection{Theoretical Level}

Theoretical level is a set of principles that form the basis of the competence approach as an expression of didactic categories in specific forms, methods, means of instruction, organizational forms of the subject activity of teachers and students with the purpose of students' mastering of specific content in a specific area of knowledge and professional activities. This can be the content and technology of education; other didactic system of teaching methods developed in relation to the educational process of the University; the didactic system of independent and research work of students; selection of learning technologies; pedagogical modeling process of core professional competencies' formation.

\subsubsection{Methodical Level}

This level is presented by theoretically and practically conditioned and tested in educational practices a set of interrelated, complementary and causing each other methods and techniques of teachers and students' subject activity in the development of students' core professional competencies and technologies of their implementation. This set is based on the content of the discipline, the teachers' performance on selection, structuring and content presentation to the students, student learning activities, technology design and implementation of a range of teaching materials. Methodical level creates the conditions for practical implementation of the methodological and theoretical levels. This is due to any methodological system in its broad social and pedagogical understanding is based on the process of transmission and assimilation of professional and social experience. The methodical system's central elements are the teacher's and student's activity, which function and evolve in the learning process based on the specific content of the training material (training contents). The teacher's activity in terms of the competence approach is primarily the activity on forecasting the relevant structures of student's activity focused on the development of core professional competencies in the humanitarian training. It is focused on processing, transforming of social and professional experience's elements - the content of professional training in the requirements of the FSES of, HPE, other curricula materials into appropriate educational materials, the organization of students' activity, and, consequently, creation of the necessary pedagogical conditions for goals' effective solutions. The second activity is an activity of exercises performed by the students. Outwardly it manifests itself in the transformation in the students' learning process of their own already existing experience through the assimilation of elements of the new social and professional experience, revised by the teacher and presented to students in the form of educational materials to be learned, as well as to update the contents of the training and the experience of self-transformation of him or herself.

These performing acts of assimilation, transformation, and self-transformation are the real practice of learning that constitute the process of the experience transferring of knowledge's turning into competencies in the process of students' transforming of the represented content of their professional training. Ideally, it should meet the needs of the student as a future specialist in the development stage. Thus, each of the activities - the teachers' and students' one - has an independent status in the structure of the educational process and acts as a methodical system of teaching and methodical system of learning. The system of instruction on level of teaching material and pedagogical reality is a system of necessary and sufficient conditions of teaching and management. The content of this system is the solution by the teacher of the following specific tasks: the selection of the content to be assimilated; transferring it into the tasks' system to be addressed; the organization of learning (an explanation, the organization of mastering by students of knowledge and ways of acting with them); selection of necessary and sufficient situation-specific forms and methods of influence on individual students and the group as a whole to manage the activities of the students in the structure of the whole pedagogical process.

Established regulations are scientific and methodical basis for the design and implementation of educational and methodical complex of students' core professional competencies' formation in the process of teaching humanitarian disciplines (normative and methodical documentation, content, learning and control tools) which 
constitute the practice - oriented structure of pedagogical conditions corresponding to the established objectives.

\section{Discussions}

The results of established complex testing of pedagogical conditions of university students' professional core competencies' formation confirm their effectiveness in the preparation of future specialist, who meets the requirements of modern reality. These formative experiment's data show a noticeable dynamics in the development of core professional competencies in humanitarian training. An important factor in confirming the efficiency of the conducted research, are data on the implementation of the high school graduates core professional competences in the labor market (see table 1).

Table1. Dynamics of core professional competences' indicators of graduates in the labor activity (data in\%)

\begin{tabular}{llc}
\hline & Competence indicators & Quantity of tested \\
\hline 1. & Readiness to innovations & 75 \\
2. & Creativity in activity & 50 \\
3. & Organizational abilities & 65 \\
4. & Abilities to work in the team & 73 \\
5. & Corporationism & 75 \\
6. & Self-organizing & 63 \\
7. & Self-transforming & 61 \\
\hline
\end{tabular}

Groups of University graduates, characterized by their readiness to pursue personal, professional, activity, communication, cultural competences possess the elements of scientific organization of labor, research and project activities, differ by their striving to integrate theoretical and professionally significant competences, participate in the work of public organizations in the creative laboratories of enterprises planning to continue research in graduate, postgraduate.

\section{Conclusion}

The conducted study confirms the theoretical and practical significance of problem solving how to form core professional competence of University students in the process of humanitarian training, mediated by the implementation of a complex of pedagogical conditions: conceptual ideas of competence-based approach, the model of professional core competencies' formation and scientific - methodological support of this process. The results of the formative experiment confirm the effectiveness of the established complex of pedagogical conditions in the core professional competences' formation of future specialists required in the modern labor market. The study does not cover all aspects of this emerging problem. Beyond the boundaries of the study remains poorly defined problem of training of teacher's personality to the design and implementation of students' core professional competencies in the conditions of innovative educational environment of the Humanities.

\section{References}

Baidenko, V. I. (2006). Competencies: to the competence-based approach mastering. Moscow.

Bespalko, V. P. (1995). Pedagogy and advanced learning technologies. Moscow.

Bestuzhev - Lada, I. V. (1996). Four conditions of humanization of education. Saint - Petersburg.

Choshanov, M. A. (2011). Didactics and engineering. Moscow.

Federal state educational standard of higher professional education in areas of training. (2009). Moscow.

Grebenyuk, O. S. (2000). Pedagogy of individuality: a course of lectures. Kaliningrad.

Ibragimov, G. I. (2012). The didactic concept of teacher training: design and technological approach. Kazan.

Khutorskoy, A.V. (2002). Core competencies and educational standards. Moscow.

Khutorskoy, A.V. (2003). Core competences. Technology of design. Public education, 5, 14-19.

Kirsanov, A. A. (2000). Methodological problems of creating a predictive model of a specialist. Kazan.

Kolesnikova, I. A. (2005). Pedagogical design. Moscow. 
Kondratiev, V. V. (2000). Fundamentalization of specialist's vocational education in the technological University. Kazan.

Kuzmina, N. V. (2001). Acmeological theory to improve the quality of training education. Moscow.

Leontiev, A. N. (1975). Activity. Consciousness. Personality. Moscow.

Masalimova, A. R., Ikramova, G. D., Shaidullina, A. R., Gubaidullina, G. T., \& Apraksina, N. D. (2014). Distant in-company foreign language learning involving university student-tutors. American Journal of Applied Sciences, 11, 1123-1127. http://dx.doi.org/10.3844/ajassp.2014.1123.1127

Nigmatov, Z. G. (1993). Pedagogy of the school. Kazan.

Novikov, A. M. (2002). Methodology of education. Moscow.

Novikov, A. M., \& Novikov, D. A. (2004). Educational project (methodology of educational activity). Moscow.

Nurutdinova, A. R. (2010). The differences of Eastern and Western approach: policy of cluster system and regional development in the era of globalization. Discussion, 7, 82-88.

Raven, J. (2002). Competence in modern society. Identification, development and implementation. Moscow.

Rozov, N. S. (1993). Philosophy of humanitarian education: the Value grounds of base humanitarian education in higher education. Novosibirsk.

Serikov, V. V. (1999). Education and identity: theory and practice of pedagogical systems designing. Moscow.

Shchedrovitsky, P.G. (1993). Essays on the philosophy of education. Moscow.

Shchelkunov, M. D. (2010). Education in XX1 century: facing the new challenges. Kazan.

Slastenin, V. A., Isaev, I. F., \& Shiyanov, E. N. (2003). Pedagogics. Moscow.

Strongin, R., \& Grudinsky, A. (2008). Project - oriented management of innovation University. Higher education in Russia, 4, 26-31.

Telegina, N. V., Galimova, E. G., \& Masalimova, A. R. (2015). The Structure and Content of the Model of Pedagogical Conditions Binary Approach to Optimization of Control and Diagnostic Functions in Teaching "General pedagogy" to Students. Asian Social Science, 11(1), 364-368.

Verbitsky, A. A. (2004). Competence approach and the theory of contextual learning. Moscow.

Volovich, L. A. (2008). Competence approach in teaching humanitarian disciplines (conceptual ideas). Kazan.

Zapesotsky, A. S. (2003). Education: philosophy, cultural studies, politics. Moscow.

Zimnyaya, I. A. (2003). Core competences - a new paradigm of education. Higher education today, 5, 34-42. Moscow.

\section{Copyrights}

Copyright for this article is retained by the author(s), with first publication rights granted to the journal.

This is an open-access article distributed under the terms and conditions of the Creative Commons Attribution license (http://creativecommons.org/licenses/by/3.0/). 